\title{
SIMPLE "Sistem Informasi Presensi Perkuliahan Elektronik" Berbasis Citra Biometrik (Studi Kasus Institut Teknologi Sumatera)
}

\author{
${ }^{1}$ Arkham Zahri Rakhman, ${ }^{2}$ Rajif Agung Yunmar \\ Program Studi Teknik Informatika, Institut Teknologi Sumatera, Lampung Selatan \\ ${ }^{2}$ Program Studi Fisika, Institut Teknologi Sumatera, Lampung Selatan \\ larkhameif.itera.ac.id \\ ${ }^{2}$ rajiflif.itera.ac.id
}

Intisari - Penghitungan tingkat kehadiran siswa di kelas sangat penting, karena indikator kredibilitas siswa yang satu ini dapat dilihat dari kehadirannya di kelas. Namun sejauh ini masih banyak kampus yang menggunakan sistem kehadiran konvensional, yaitu keberadaan dengan menggunakan tanda tangan di selembar kertas. Kehadiran seperti ini sangat rentan terhadap tindakan tidak adil, seperti pemalsuan tanda tangan. Selain itu, kehadiran konvensional juga menyulitkan administrator akademik untuk memasukkan semua subjek ke dalam basis data. Penggunaan sistem kehadiran elektronik dengan memanfaatkan gambar biometrik atau sidik jari adalah langkah yang tepat untuk mengatasi masalah ini. Penelitian ini dilakukan di Program Studi Teknik Informatika Institut Teknologi Sumatra.

Kata kunci — sidik jari, biometrik, presensi.

Abstract - Calculation of the level of attendance of students in the class is very important, Because this one indicator of student credibility can be seen from its presence in class. But so far there are still many campuses that use conventional presence systems, that is presence by using a signature on a piece of paper. Presence like this is very vulnerable to unfair actions, such as signature forgery. In addition, conventional presence also makes it difficult for academic administrators to input all subject into the database. The use of electronic presence system by utilizing biometrics images or fingerprints is the right step to overcome these problems. This research was conducted in the Informatics Engineering Study Program of the Sumatra Institute of Technology.

Keywords - fingerprint, biometrics, presence 


\section{PENDAHULUAN}

Sistem presensi konvensional telah dikenal sejak zaman dahulu kala. Pada mulanya, sistem presensi menggunakan kertas sebagai medianya, presensi dilakukan secara manual dengan cara memanggil nama dari daftar yang telah ada, kemudian menandai hasilnya [1]. Presensi perkuliahan konvensional memiliki banyak keterbatasan, diantaranya adalah kesulitan dalam merekap data yang dapat berdampak kepada sulitnya kontrol terhadap suatu perkuliahan. Disamping itu terdapat resiko dari orang-orang yang tidak bertanggung jawab, misalnya kasus kecurangan pada pengisian kehadiran [2].

Perkembangan teknologi informasi telah dirasakan manfaatnya secara luas dalam kehidupan umat manusia. Demikian pula dengan dunia pendidikan, sebagian besar kegiatan akademik saat ini tidak lepas dari kemajuan teknologi informasi. Pemanfaatan teknologi informasi sedemikian canggih dapat menunjang keberhasilan pembelajaran [2]. Dengan adanya teknologi informasi, maka presensi yang pada mulanya dilakukan secara konvensional dapat ditransformasi kedalam bentuk elektronik.

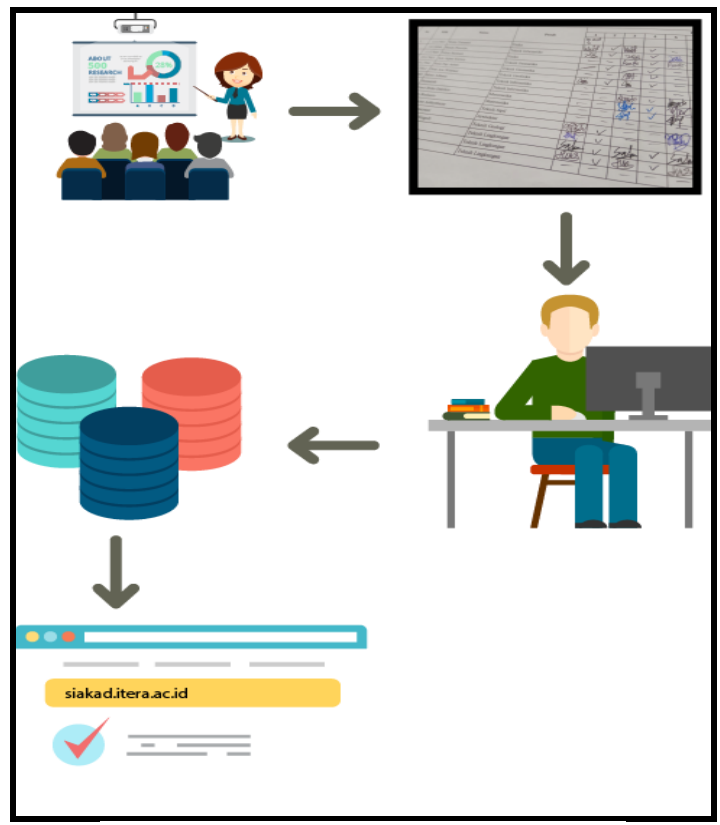

Gbr 1. Alur presensi konvensional
Dewasa ini muncul sistem presensi elektronik berbasiskan biometrik, yaitu sistem presensi yang menggunakan biometrik untuk mengenali seseorang dalam sebuah proses presensi [1]. Biometrik adalah teknologi untuk mengenali seseorang berdasarkan karakteristik khusus yang melekat pada seseorang, yang tidak ada orang lain didunia ini memiliki karakteristik biometrik yang sama. Karakteristik yang dimaksud dapat berupa sidik jari, bentuk wajah, iris, maupun suara. Pengenalan biometrik melalui sidik jari manusia terbukti handal, akurat, dan aman dibandingkan dengan metode biometrik lain seperti iris, wajah, maupun suara [3]

Pengembangan presensi elektronik menggunakan sidik jari dengan segala kelebihannya diharapkan dapat menghilangkan kelemahan-kelemahan yang ada pada sistem presensi konvensional. Presensi perkuliahan elektronik diharapkan dapat mempermudah kontrol stakeholder (SPM, Prodi, Fakultas, pimpinan, dan orang tua mahasiswa) terhadap jalannya perkuliahan. Mulai dari kontrol terhadap kehadiran dosen dan mahasiswa dalam perkuliahan yang dapat dimonitor secara akurat, kontrol terhadap materi perkuliahan, dsb. Selain itu presensi berguna untuk mendeteksi mahasiswa yang bermasalah. Dimana salah satu indikatornya adalah minimnya jumlah kehadiran mahasiswa tersebut didalam kelas. Data- data kuliah dan presensi tersebut yang apabila diolah dengan baik, maka dapat menjadi input dari pengambilan keputusan bagi stakeholder yang terkait.

Penelitian ini bertujuan untuk merancang dan mengembangkan sistem presensi perkuliahan elektronik yang baik dan tepat guna, sehingga output (dalam bentuk perangkat lunak) yang dihasilkan diharapkan dapat bermanfaat dan digunakan dalam jangka panjang.

Penelitian ini bertujuan untuk mengembangkan sistem presensi perkuliahan elektronik yang tepat guna, handal, dan akurat yang diharapkan dapat 
meningkatkan kualitas belajar mengajar di sebuah institusi.

\section{TINJAUAN PUSTAKA}

Konsep terkait presensi elektronik menggunakan sidik jari telah diusulkan oleh sejumlah peneliti sebelumnya. Berbagai perbedaan ditemukan pada penelitian-penelitian tersebut meliputi arsitektur sistem, perangkat pemrosesan, metode pengenalan sidik jari, metode pengiriman data, metode penyimpanan data, dan lain sebagainya.

Basheer dan Raghu mengembangkan sistem presensi elektronik portable berbasis microcontroller yang digunakan dalam lingkup kampus. Perangkat presensi selalu dibawa saat pengajar memasuki ruang kelas. Perangkat presensi diedarkan secara bergilir kepada mahasiswa selama berjalannya perkuliahan. Selesai perkuliahan perangkat presensi akan dikembalikan ke bagian akademik fakultas untuk transfer data hasil presensi [4].

Walia dan Jain merancang sistem presensi elektronik berbasis mesin Arduino, proses pengenalan sidik jari tidak memerlukan basis data eksternal, pengenal pengguna dilakukan pada internal modul fingerprint, bukan pada Arduino. Hasil pengenalan akan disimpan di memori sementara Arduino untuk selanjutnya disimpan secara permanen pada file teks melalui LabVIEW [5].

Potadar, dkk. dalam penelitiannya mengusulkan penggunaan modul wireless Zigbee untuk pengiriman data hasil presensi. Pengenalan dilakukan di internal modul sidik jari, dengan demikian proses pengenalan tidak memerlukan basis data eksternal. Microcontroller sebagai jantung dari sistem bertugas mengatur pengiriman data, melakukan proses presensi (Potadar et al. 2015).

Yongqiang dan Ji mengusulkan arsitektur sistem client-server dalam pembuatan perangkat presensi elektronik. Pada sisi client digunakan modul radio frequency yang berfungsi dalam pengiriman data hasil presensi dengan berbagai pengaturan, yaitu: dikirimkan segera, dengan jangka waktu tertentu, atau berdasarkan respon. Server bertugas lebih lanjut mengolah data hasil presensi [6].

\section{METODOLOGI PENELITIAN}

Perancangan arsitektur sistem merupakan langkah awal dalam pengembangan sistem presensi elektronik. Output yang dihasilkan dari tahapan ini adalah gambaran mengenai komponenkomponen teknis yang terlibat, juga gambaran mengenai bagaimana sistem ini nantinya akan bekerja.

Sistem presensi elektronik terdiri dari beberapa komponen yang saling berhubungan, di antaranya adalah terminal, server, dan jaringan LAN. Terminal diposisikan pada masing-masing ruang kelas. Terminal terdiri dari satu buah microcomputer dan satu (atau beberapa dengan mode paralel) alat perekam sidik jari, hal ini seperti biasa dilihat pada Gambar 2 .

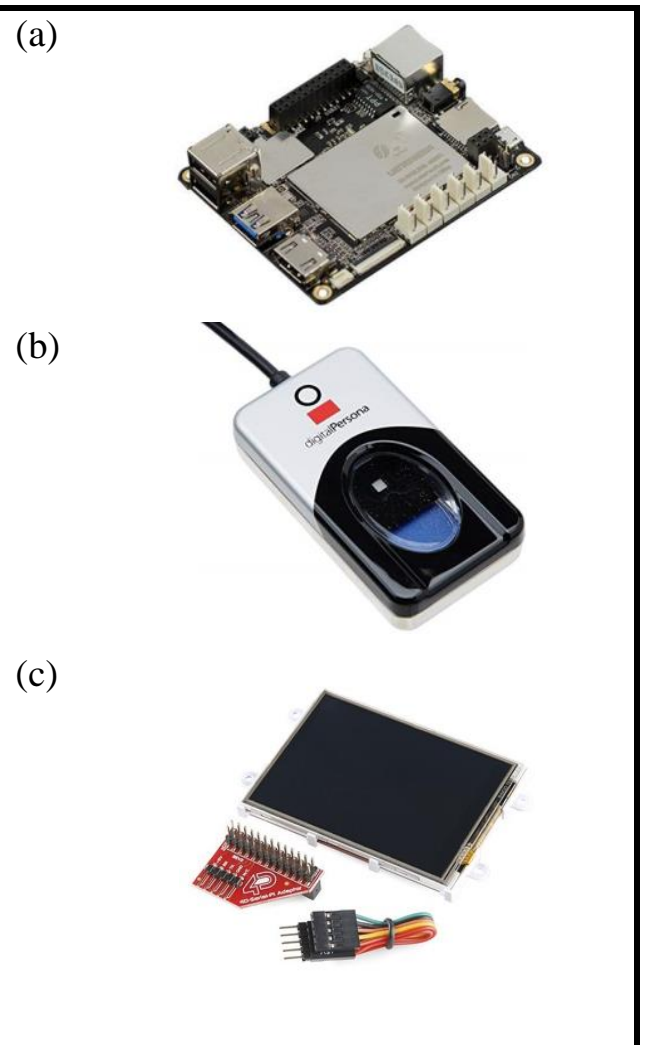

Gbr 2. Microcomputer Lattepanda (a), modul sidik jari (b), mini LCD touchscreen (c) 
Alur kerja detail dari arsitektur sistem presensi elektronik menggunakan sidik jari diatas dapat dilihat pada flowchart pada Gambar 3 berikut ini.

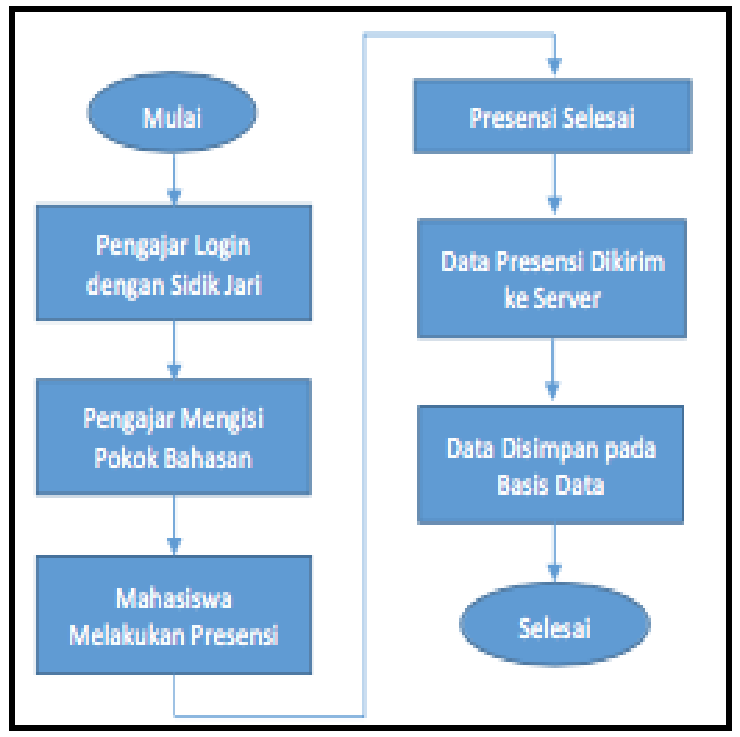

Gambar 3. Alur kerja sistem

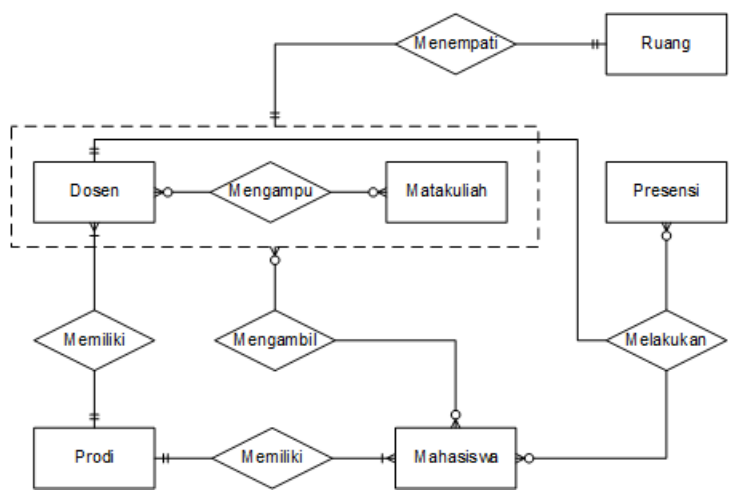

Gbr 4. Alur basis data sistem presensi elektronik

Rancangan basis data yang digunakan dalam sistem presensi elektronik menggunakan sidik jari dapat dilihat pada diagram Entity Relationship (ER) seperti yang nampak pada Gambar 4 di atas.

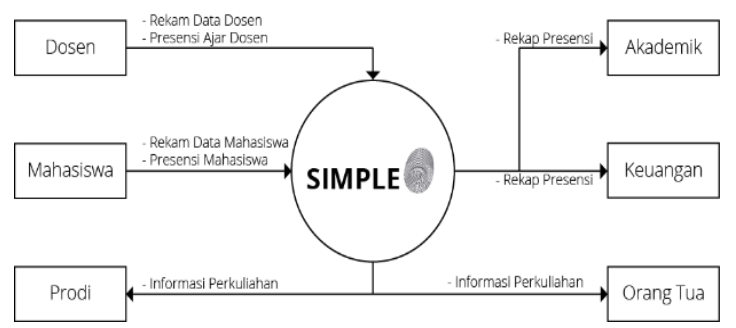

Gbr 5. Alur data pada sistem presensi elektronik SIMPLE
Sistem presensi elektronik SIMPLE ini memiliki alur sistem seperti pada gambar 5 di atas. Bukan hanya sebatas presensi, namun juga terintegrasi dengan sistem akademik dan menjadi di Institut Teknologi Sumatera.

Dengan adanya sistem terintegrasi maka akan sangat mempermudah pimpinan institusi memantau aktifitas kegiatan belajar mengajar guna meningkatkan kualitas pendidikan di institusi tersebut. Terlihat di Gambar 5, Dosen selain melakuan presensi juga mencatat poin poin materi yang disampaikan di perkuliahan tersebut.

\section{IMPLEMENTASI SISTEM}

Pada tahapan ini, sistem presensi yang telah dirancangan sebelumnya akan di implementasikan dengan perangkat lunak tertentu. Microcomputer akan diinstall dengan sistem operasi Windows IoT, perangkat lunak basis data yang digunakan adalah MySQL, sedangkan bahasa pemrograman yang digunakan dalam pengoperasian sistem, mulai dari pengenalan sidik jari, pengolahan data, penyajian informasi, dan lain sebagainya menggunakan bahasa pemrograman C\#.

Pada awal pembuatan sistem hal pertama yang harus diperharikan adalah menguji penggunaan sensor biometrik. Sensor biometric yang digunakan pada sistem ini adalah modul sensor biometric dengan tipe digital persona $\mathrm{u}$ are $\mathrm{u} 4500$ seperti pada gambar 2 poin $b$.

Verifikasi sidik jari adalah proses membandingkan data sidik jari dengan template sidik jari yang dihasilkan saat pendaftaran dan memutuskan apakah keduanya cocok. Berikut ini prosedur verifikasi sidik jari :

1. Dapatkan Pengenal Subjek dari orang yang akan diverifikasi.

2. Ambil sampel sidik jari menggunakan pembaca sidik jari. 
3. Ekstrak fitur sidik jari yang ditetapkan untuk tujuan verifikasi dari sampel sidik jari.

4. Ambil template sidik jari yang terkait dengan Identifier Subjek dari repositori Anda.

5. Lakukan perbandingan antara set fitur sidik jari dan template sidik jari, dan buat keputusan pertandingan.

Berikut adalah gambaran langkahlangkah pada saat pengambilan template set dan proses verifikasi

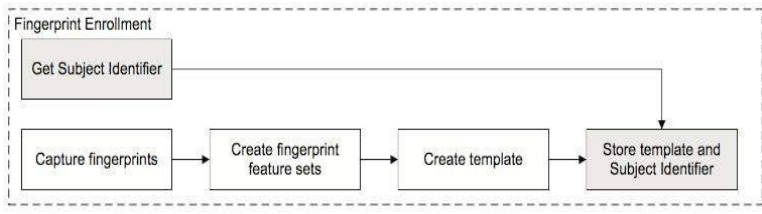

Gbr 6. Proses pengambilan template set.

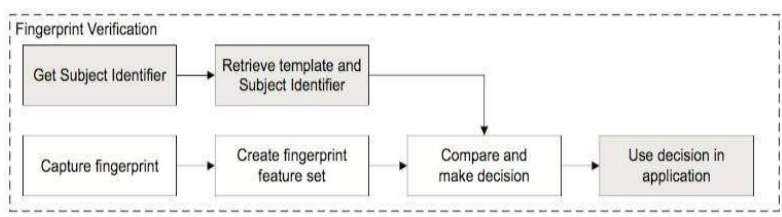

Gbr 7. Proses verifikasi sidik jari subjek dan template set.

Pada proses verifikasi sidik jari, data yang diinput oleh subjek (citra sidik jari) akan dicari kesamaannya pada data template set yang telah diinput sebelumnya.

Sistem pengenalan sidik jari memberikan banyak keuntungan, keamanan dan kenyamanan dibandingkan metode presensi tradisional. Namun, pada dasarnya mereka adalah sistem pengenalan pola yang secara inheren kadang-kadang membuat kesalahan tertentu. Selama verifikasi, kadang-kadang seseorang yang terdaftar secara sah ditolak oleh sistem (false negative), dan kadang-kadang orang yang tidak terdaftar diterima oleh sistem (true positive).

\section{A. Hasil Implementasi}

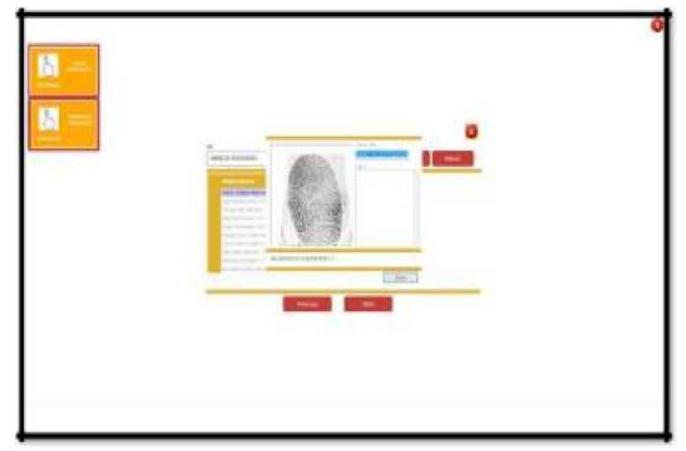

(a)

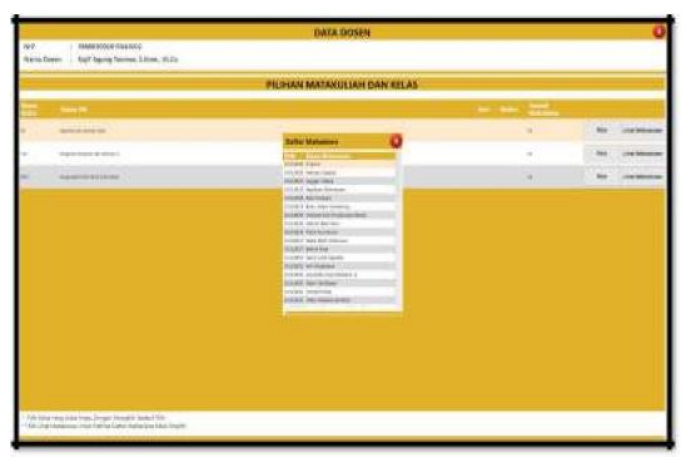

(b)

Gbr 8. Antar muka sistema presensi elektronik SIMPLE

\section{B. Uji Coba}

Setelah melakukan uji coba fungsional didapatkan rincian apakah fitur-fitur aplikasi telah berjalan dengan baik, seperti yang ditampilkan pada tabel berikut:

Tabel 1. Pengujian sistem

\begin{tabular}{|l|l|c|}
\hline \multicolumn{3}{|c|}{ Dosen } \\
\hline No & \multicolumn{1}{|c|}{ Pengujian } & Hasil \\
\hline $\mathbf{1}$ & Pengujian login & Berhasil \\
\hline $\mathbf{2}$ & $\begin{array}{l}\text { Pengujian menampil } \\
\text { profil matakuliah yang } \\
\text { diampu dosen tersebut }\end{array}$ & Berhasil \\
\hline $\mathbf{3}$ & $\begin{array}{l}\text { Pengujian memilih } \\
\text { matakuliah }\end{array}$ & Berhasil \\
\hline $\mathbf{4}$ & Pengujian mengisi SAP & Berhasil \\
\hline $\mathbf{5}$ & Pengujian membuka & \\
\hline
\end{tabular}




\begin{tabular}{|l|l|c|}
\hline & $\begin{array}{l}\text { halaman login } \\
\text { mahasiswa }\end{array}$ & Berhasil \\
\hline $\mathbf{6}$ & Pengujian logout & Hasil \\
\hline \multicolumn{3}{|c|}{ Mahasiswa } \\
\hline No & \multicolumn{1}{|c|}{ Pengujian } & Berhasil \\
\hline $\mathbf{1}$ & $\begin{array}{l}\text { Pengujian presensi } \\
\text { dengan sidik jari yang } \\
\text { telah didaftarkan }\end{array}$ & $\begin{array}{l}\text { Berhasil(Gagal } \\
\text { Login) } \\
\text { jari yang belum } \\
\text { didaftarkan }\end{array}$ \\
\hline
\end{tabular}

\section{KESIMPULAN DAN SARAN}

\section{A. Kesimpulan}

Kontribusi dari penelitian ini adalah penerapan sistem tepat guna untuk meminimalisir tindak kecurangan mahasiswa dalam melakukan presensi perkuliahan dengan menggunakan sensor biometric (sidik jari). Dari sistem ini dapat disimpulkan kegunaannya, antara lain :

1. Menekan angka kecuarangan mahasiswa seperti titip presensi

2. Memantau jumlah kehadiran dengan minimal kehadiran $80 \%$ untuk dapat mengikuti Ujian Akhir Smester.

3. Implementasi dari sistem ini tidak hanya sebagai alat bantu presensi, tetapi juga sebagai sistem pemantauan kualitas pendidikan di perguruan tinggi yang dimonitor oleh Satuan Penjaminan Mutu (SPM). Selain mahasiswa, dosen pun dipantau aktifitas belajar mengajarnya seperti disiplin jam masuk, jam berakhir perkuliahan, dan kesesuaian materi dengan silabus.

\section{B. Saran}

Ada beberapa saran yang dapat diberikan terkait dengan SIMPLE "Sistem Informasi Presensi Perkuliahan Elektronik" Berbasis Citra Biometrik ini, antara lain :

1. Penggunaan case yang lebih kokoh ataupun hardware yang permanen ditiap kelas.
2. Penambahan fitur seperti upload materi perkuliahan akan menambah fingsionalitas sistem.

\section{UCAPAN TERIMA KASIH}

Penelitian ini didukung oleh Direktorat Penelitian dan Pengabdian kepada Masyarakat, Direktorat Jenderal Penguatan Penelitian dan Pengembangan Kementerian Riset, Teknologi, dan Pendidikan Tinggi Republik Indonesia melalui skema Penelitian Dosen Pemula (PDP). Kami juga berterima kasih kepada rekan-rekan kami dari Institut Teknologi Sumatera yang memberikan wawasan dan ide yang sangat membantu penelitian ini.

\section{REFERENSI}

[1] Harris, A. J., \& Yen, D. C. (2002). Biometric authentication: assuring access to information. Information Management \& Computer Security, 10(1), 12-19.

[2] Jain, A. K., Ross, A., \& Prabhakar, S. (2004). An introduction to biometric recognition. IEEE Transactions on circuits and systems for video technology, 14(1), 4-20.

[3] Jain, A.K., Ross, A. \& Prabhakar, S., 2004. An Introduction to Biometric Recognition. IEEE Transactions on Circuits and Systems for Video Technology, 14(1), pp.4-20.

[4] Basheer K.P., M. \& C.V., R., 2012. Fingerprint Attendance System for Classroom Needs. In 2012 Annual IEEE India Conference (INDICON). pp. 433438.

[5] Walia, H. \& Jain, N., 2016. Fingerprint Based Attendance System Using LabVIEW and GSM. International Journal of Innovative Research in Science, Engineering and Technology, 5(7), pp.12064-12072.

[6] Yongqiang, Z. \& Ji, L., 2006. The Design of Wireless Fingerprint Attendance System. In 2006 International Conference on Communication Technology. 